\title{
Fiscal Storms: \\ Public Spending and Revenues in the Aftermath of Natural Disasters
}

\author{
Ilan Noy* \\ Department of Economics \\ University of Hawai'i at Manoa \\ and \\ Aekkanush Nualsri* \\ Department of Economics \\ University of Hawai'i at Manoa \\ Working Paper No. 08-09 \\ December 2008
}

\begin{abstract}
Recent research in both the social and natural sciences has been devoted to increasing our ability to predict disasters, prepare for them and mitigate their costs. Curiously, we appear to know very little about the fiscal consequences of disasters. The likely fiscal impact of a natural disaster has not been examined before in any comparable or comparative framework. We estimate and quantify the fiscal consequences of natural disasters using quarterly fiscal and disaster data for a large panel of countries. In our estimations, we employ a panel VAR framework that is similar to Burnside et al. (Journal of Economic Theory, 2004), that also controls for the business cycle. We find fiscal behavior in the aftermath of disasters in developed countries that can best be characterized as countercyclical. In contrast, we find pro-cyclical decreased spending and increasing revenues in developing countries following large natural disasters. We quantify these effects.
\end{abstract}

Keywords: natural disasters, fiscal policy

JEL codes: E62, O23, Q54

* noy@hawaii.edu; aekkanus@hawaii.edu. Both authors are at the University of Hawai'i, Manoa, 2424

Maile Way, Honolulu, HI 96822. We thank Inessa Love for providing us with her STATA routines. 
The canton of Unterwald in Switzerland is frequently ravaged by stoms and inundations, and is thereby exposed to extraordinary expences. Upon such occasions the people assemble, and every one is said to declare with the greatest frankness what he is worth in order to be taxed accordingly.

(from The Wealth of Nations by Adam Smith, book V chapter II)

\section{Introduction}

Natural disa sters have resulted in signific ant economic and human loss long before Adam Smith wrote about the Unterwald. Major catastrophic events-recently the Indian Ocean tsunami, the Kashmir and Sichuan earthquakes and Huric ane Katrina-repeatedly bring the human and materia I cost of these crises to the forefront of public attention world wide. Natural disasters a lso figure prominently in controversia I disc ussions a bout global wa ming, especially in relation to the attendant changes in the pattems of climatic events and sea levels that a re predicted to accompany such warming (IPCC , 2007). ${ }^{1}$ The United Nation's Integrated Regional Info mation Network notes, "Over the past decade, the total [number of people] affected by natural disasters has tripled to 2 billion." (IRIN, 2005). Therefore, much research in both the social and natural sciences has been devoted to inc reasing our ability to predict disasters, prepare for them and mitigate their costs. Curiously, we are una ware of any research that attempts to quantify the impact of natural disasters on the public purse. We appear to know very little about the typical fisc a l consequence of disa sters.

\footnotetext{
1 Increasing levels of greenhouse gases, changing sea, land and a ir temperatures, rising sea levels, changing pattems of ra in and snow and an unstable climate a re all likely cata lysts of future events.
} 
In developing the EM-DATintemational database on disasters, a signific ant research effort has gone into mea suring the primary costs of disasters in terms of human lives lost, the number of people directly affected, and the damage to property and infrastructure. In a recent emerging literature, several papers have used this data to examine the deteminants of these economic costs (Anbarci et al., 2005; Kahn, 2004; Raschky, 2008; and Skidmore and Toya, 2007). Some further work has estimated the short- and long-run secondary impacts of disaster on production, productivity and output (Cavallo and Noy, 2008; Cuaresma et al., 2008; Noy, 2009; and Skidmore and Toya, 2002). However, the likely fiscal impact of a natural disaster has not been examined before in any comparable or comparative framework.

On the expenditure side, the disaster reconstruction costs to the public may be very different than the original magnitude of destruction of capital that occurred. For example, the cost for delivering and supplying populations with both short-tem survival needs and longer tem reconstruction may be fraught with logistic al expenses and can also lead to other macroeconomic dynamics that will have an adverse impact on the govemment's fiscal spending. On the other hand, it is also possible that the added reconstruction costs be lower, especially if much of the capital that was destroyed is no longer necessary, was anyway becoming obsolete, is cheaper to replace or because of wide-scale loss of life. In such cases, the fiscal spending burden may potentially be smaller (see Fengler et al., 2008 for more detail on these possibilities).

On the other side of the fisc al ledger, the impact of disasters on tax and other revenue sources has also not been quantita tively examined. To a large extent, impacts on revenue depend on the macroeconomic dynamics occuming following the disaster shock, and the structure of revenue sources (income taxes, consumption taxes, custom dues, etc.) since each may react differently in the aftermath of the disaster event. 
Obta ining accurate estimates of the likely fiscal costs of a disa ster is useful in enabling better cost-benefit evaluation of various mitigation programs. These should a Iso assist foreign a id organizations and intemational multilateral institutions in planning and preparing their programs. Another motivation to estima te the fiscal cost is to better enable govemments to directly insure against disaster losses, indirectly through the issuance of catastrophic bonds (CAT bonds), or through precautionary saving. ${ }^{2}$ The only attempt we know of estima ting the likely fiscal insurance needs of a govemment has been calculated for Belize (Borensztein et al., 2008); though whether these estimates for Belize apply elsewhere is an unexplored question.

We estimate the fiscal consequences of natural disa sters using quarterly fiscal data for a large panel of countries. In our estimations, we employ a panel VAR framework that also controls for the business cycle. We find fiscal behavior in the aftermath of disa sters in developed countries that can be characterized as counter-cyclical, but pro-cyclical decreased spending and increasing revenues in developing countries following large natural disa sters.

\section{Data}

Our data set includes 22 developed and 20 developing countries; only data ava ilability restricted our sample (see the appendix for a list of countries). We collected quartenly data on natural disasters and govemment finance for the period from 1990 to 2005. The natural disaster data is extracted from the EMDATdatabase collected by the Centre for Research on the Epidemiology of Disasters (CRED). ${ }^{3}$ The EM-DATdatabase provides information on world wide disasters compiled from various sources, including UN agencies, non-

\footnotetext{
2 Bamichon (2008) calcula tes the optimal a mount of intemational reserves for a country facing extemal disa ster shocks using a calibrated model.

${ }^{3}$ CRED is based at the Catholic University of Louvain in Belgium. The EM-DATdata is public ly available on CRED's web site at: www.cred.be/
} 
govemmental organizations, insurance companies, research institutions and press agencies. Disasters reported in the database include hydrometeorologic al disasters (floods, wave surges, stoms, droughts, landslides and a va lanches), geophysic al disa sters (earthquakes, tsuna mis and volc a nic enuptions), and biological disasters (epidemic s and insect infestations). CRED defines a disaster as a natural situation or event which overwhelms local capacity necessitating a request for extemal assistance. Specific a lly, at least one of the four criteria must be fulfilled: (1) 10 or more people reported killed; (2) 100 people reported affected; (3) declaration of a state of emergency; or (4) call for intemational a ssistance. ${ }^{4}$

We construct a series of standardized qua rterly disaster variables which reflect the magnitude of these disasters. We aggregate the a mount of direct damage from disaster events reported in the EM-DATdatabase for a country in a given quarter, and then divided by country's GDP from the same quarter of previous year to facilitate cross-country comparisons. ${ }^{5}$ The data on quarterly GDP comes from the Intemational Finance Statistics (IFS) database provided by the Intemational Monetary Fund (IMF). ${ }^{6}$

Table 1 reports the summa ry statistic s of our disa ster va ria ble. It seems very likely that the fina ncial cost of disa ster rela tes to the level of development. Over the period from 1990-2005, the average damage a mount from disasters is more than three times higher in developing countries tha $n$ in developed countries

\footnotetext{
4 The number of people killed includes "persons confimed as dead and persons missing and presumed dead"; people affected a re those "requining immediate assistance during a period of emergency, i.e. requining basic survival needs such as food, water, shelter, sa nitation and immedia te medical a ssistance."

${ }^{5}$ Note that we do not use current GDP to standardize the disaster damage since the current GDP has been affected by the disaster itself.

6 From the outset, it should be clear that doubts have been expressed a bout the accuracy of data on natural disasters; especially because often the major source of these data (national govemments) hasan interest in inflating the measured impact. Yet, since biases should by consistent, using data from one source should provide information about the relative magnitude of disasters and should thus be appropriate for the hypotheses we examine here, and for our empirical predictions regarding an a verage disaster's likely impact.
} 
(1.095 vs. 0.309). This result is widely reported in the litera ture, with most explanations emphasizing the capacity of rich nations to better prepare and mitigate the cost of disa sters.

Table 1. Summary Statistics of Disaster Variable

\begin{tabular}{crrrrr}
\hline Sample & Countries & Obs & Mean & $\begin{array}{r}\text { Std. } \\
\text { Dev. }\end{array}$ & Max \\
\hline Developed countries & $\mathbf{2 2}$ & $\mathbf{1 4 0 8}$ & $\mathbf{0 . 3 0 9}$ & $\mathbf{0 . 7 3 5}$ & $\mathbf{5 . 9 2 1}$ \\
Developing countries & $\mathbf{2 0}$ & $\mathbf{1 2 5 1}$ & $\mathbf{1 . 0 9 5}$ & $\mathbf{3 . 0 3 3}$ & $\mathbf{2 9 . 1 7 9}$ \\
UpperMiddle Income & 11 & 690 & 0.799 & 2.164 & 11.322 \\
Lower Middle Income & 9 & 561 & 1.257 & 3.413 & 29.179 \\
\hline
\end{tabular}

Notes: See the appendix for list of countries. Means and standard deviations a re computed from disaster episodes only; number of observations denotes the total number of quarterly observations we obta in for each sample, including 'no disa ster' observations.

Data on fiscal policy is prima rily taken from the section on govemment finances in the IFS database (this data was supplemented by data from the Govemment Finance Statistic S CD-ROM, a Iso a vailable from the IMF). The govemment finance data includes cash flows of the budgetary central govemment (the Statement of Sources and Uses of Cash) and/or accrual flows of the consolidated general govemment (the Statement of Govemment Operations). The two statements broadly correspond to each other, but with variation in the teminology used. In the analysis, we examine five fiscal varia bles: govemment consumption (govcon); govemment revenue (govrev); govemment payment (govpay); govemment cash surplus (govsurp); and govemment outstanding debt (govdebt). We remove sea sonal effects using the X12 seasonal a djustment method and present the data as percent of GDP.

Govemment consumption (line 91f, IFS) c onsists of consumption expend iture incurred by general govemment. The govemment revenue (line c 1 /or a 1, IFS) consists of four ma in components: taxes; soc ial contribution; grants; and other receipts. The govemment payment (line c2 /or a2,IFS) includes compensation of employees, purchase of goods and services, consumption of 
fixed capital, interest payment, subsidies, grants, social benefits, a nd other payments. The govemment cash surplus or govemment net lending (line ccsd, /or a nlb, IFS) is the net result of the net cash balance or net operating balance and the net acquisition of nonfina ncial assets. The govemment outstanding debt (line c63 / or a63, IFS) refers to the direct and assumed debt of the reporting level of govemment.

Table 2 displays the main desc riptive statistic s of the fisc al variables. The size of govemment is c learly la rger in developed countries. However, uppermiddle income countries have on average lower fiscal defic its than developed countries while the lower-middle income countries have the largest average defic its (the sample mean of govsurp $=-2.3 \%$ of GDP). Notice that the outstand ing debt va riable conta ins substa ntially fewer observations, and should be interpreted with caution. In addition, though the govemment debt is usua lly stated in percent of annual GDP, the debt data presented here is divided by qua rterly GDP.

Table 2. Summary Statistics of Fiscal Variables

\begin{tabular}{|c|c|c|c|c|c|c|c|}
\hline $\begin{array}{l}\text { Variabl } \\
\text { e }\end{array}$ & Sample & Cou & Obs & Mean & Std. Dev. & Min & Max \\
\hline \multirow{4}{*}{$\begin{array}{l}\text { govco } \\
\text { n }\end{array}$} & Developed & 22 & 1352 & 19.498 & 4.048 & 10.956 & 29.785 \\
\hline & Developing & 20 & 1052 & 14.635 & 5.648 & 5.452 & 35.181 \\
\hline & Upper Middle Inc. & 11 & 596 & 16.832 & 5.871 & 7.796 & 35.181 \\
\hline & $\begin{array}{l}\text { Lower Middle } \\
\text { Inc. }\end{array}$ & 9 & 456 & 11.763 & 3.746 & 5.452 & 23.335 \\
\hline \multirow[t]{4}{*}{ govrev } & Developed & 20 & 843 & 23.489 & 13.945 & 3.339 & 59.351 \\
\hline & Developing & 17 & 745 & 17.219 & 10.208 & 2.579 & 68.503 \\
\hline & $\begin{array}{l}\text { Upper Middle } \\
\text { Inc. }\end{array}$ & 9 & 388 & 17.271 & 13.292 & 2.964 & 68.503 \\
\hline & $\begin{array}{l}\text { Lower Middle } \\
\text { Inc. }\end{array}$ & 8 & 357 & 17.162 & 5.070 & 2.579 & 34.991 \\
\hline \multirow{2}{*}{$\begin{array}{l}\text { govpa } \\
\text { y }\end{array}$} & Developed & 20 & 872 & 25.657 & 14.681 & 1.932 & 57.033 \\
\hline & Developing & 17 & 737 & 18.329 & 10.428 & 2.470 & 53.917 \\
\hline
\end{tabular}




\begin{tabular}{|c|c|c|c|c|c|c|c|}
\hline & Upper Middle Inc. & 9 & 380 & 17.441 & 13.358 & 2.470 & 53.917 \\
\hline & $\begin{array}{l}\text { Lower Middle } \\
\text { Inc. }\end{array}$ & 8 & 357 & 19.273 & 5.757 & 2.617 & 36.006 \\
\hline \multirow[t]{4}{*}{$\begin{array}{l}\text { govsur } \\
\text { p }\end{array}$} & Developed & 20 & 902 & -1.122 & 4.279 & 21.220 & 18.760 \\
\hline & Developing & 16 & 745 & -1.292 & 3.414 & 17.844 & 18.726 \\
\hline & $\begin{array}{l}\text { Upper Middle } \\
\text { Inc. }\end{array}$ & 8 & 388 & -0.359 & 3.614 & -17.844 & 18.726 \\
\hline & Lower Middle Inc. & 8 & 357 & -2.307 & 2.859 & -13.717 & 10.039 \\
\hline \multirow{4}{*}{$\begin{array}{l}\text { govde } \\
\text { bt }\end{array}$} & Developed & 11 & 628 & 37.012 & 20.553 & 1.664 & 75.396 \\
\hline & Developing & 7 & 300 & 23.471 & 19.381 & 1.466 & 74.069 \\
\hline & Upper Middle Inc. & 5 & 236 & 26.157 & 20.376 & 5.329 & 74.069 \\
\hline & $\begin{array}{l}\text { Lower Middle } \\
\text { Inc. }\end{array}$ & 2 & 64 & 13.568 & 10.366 & 1.466 & 30.156 \\
\hline
\end{tabular}

\section{Methodology}

Eichenbaum and Fisher (2005) estimate the impact of the 9/11/2001 terrorist attacks on the U.S. govemment's fisc al accounts. Our a im in this paper is similar to theirs; we would like to describe the typic al fisc al policy response following a large exogenous shock, a natural disaster, in a panel of developed and developing countries. In tems of the methodology we use, this paper is closest to Bumside et al. (2004) that described macroeconomic developments in the United States following three large exogenous fiscal shocks. The shocks they identify are the Korean War, the Vietnam War, and the Carter-Reagan military build-up. In their work, they use a VAR methodology that is in principle identic al to ours; though our use of a panel necessitates a different estimation procedure. ${ }^{7}$

We estimate a panel vector autoregression (PVAR) model and the corresponding impulse-response functions. The reduced form equation is:

\footnotetext{
7 Two other examples of a VAR estimation with fiscal data but in different contexts are Blanchard and Perotti (2002) and llzetzki and Végh (2008).
} 


$$
\boldsymbol{x}_{i, t}=\Phi_{0}+\sum_{j=1}^{4} \Phi_{j} \boldsymbol{x}_{i, t-j}+\boldsymbol{\alpha}_{i}+\boldsymbol{\lambda}_{t}+\boldsymbol{e}_{i, t}
$$

(1)

where $\boldsymbol{x}_{i, t}$ is a two-variable vector: $\{d$ isa ster, fiscal $\}, \alpha_{i}$ is a vector of countryspecific effects, $\lambda_{t}$ is a vector of time-effects, and $\boldsymbol{e}_{i, t}$ is an i.i.d. disturbance vector. Specific ally, the bivariate vector $\{d$ isaster, fisc al\} encompasses five model spec ific ations that correspond with the five fiscal va riables we exa mine: govemment consumption, revenue, payments, surplus and debt.

As suggested in Love and Zcc hino (2006), the original varia bles a re timedemeaned and the fixed-individual effects a re removed by Helmert transformation method. ${ }^{8}$ We test for stationarity by implementing a number of panel unit root tests. The test results a re reported in Table 3A and 3B; in all cases we clearly reject the unit root null. The model is estimated using a genera lized method of moments (GMM) estimation with untransformed va riables used as instruments for transformed va riables. Numeric al impulse-response is computed from the estimated PVAR coeffic ients. We perform the Monte Carlo simulation to the estimated standard emors to generate $10^{\text {th }}$ and $90^{\text {th }}$ percentiles of the distribution which will be used as a confidence interval of the impulse-response. The number of repetition is 1000 times.

Table 3A. Panel Unit Root Test Results: Developed Countries

Null Hypothesis: Unit Root

\begin{tabular}{lrrrrrr}
\hline \multicolumn{1}{c}{ Variable } & \multicolumn{2}{c}{ IPS } & \multicolumn{2}{c}{ ADF-Fisher } & \multicolumn{2}{c}{ PP-Fisher } \\
\cline { 2 - 7 } & W-stat & P-value & \multicolumn{2}{c}{$\begin{array}{c}\text { Chi- } \\
\text { square }\end{array}$} & P-Value & \multicolumn{2}{c}{$\begin{array}{c}\text { Chi- } \\
\text { square }\end{array}$} & P-value \\
\hline dam & -30.521 & 0.000 & 726.104 & 0.000 & 956.318 & 0.000 \\
govcon & -3.816 & 0.000 & 84.909 & 0.000 & 102.631 & 0.000 \\
govrev & -3.205 & 0.001 & 79.429 & 0.000 & 139.665 & 0.000 \\
govpay & -4.211 & 0.000 & 95.005 & 0.000 & 137.100 & 0.000
\end{tabular}

8 The procedure implements forward mean-differencing which preserves the orthogonality between transformed and untransformed variables. 


\begin{tabular}{lrrrrrr} 
govsump & -7.616 & 0.000 & 166.438 & 0.000 & 278.033 & 0.000 \\
govdebt & -2.354 & 0.009 & 56.629 & 0.005 & 56.106 & 0.005 \\
\hline
\end{tabular}

Notes: (1) Variables shown are transformed variables using time-demeaned and Helmert fixed-effects transformation methods. (2) Lag length selection is based on AIC criteria. (3) IPS test is the test proposed by Im, Pesaran, and Shin (2003), (4) ADF-Fisher, and PP-Fisher tests are Fisher-type tests using ADF and PP proposed by Maddala and Wu (1999). (5) The test results for time-demeaned variables (without Helmert) are not shown here. However, we find that all the three tests reject the unit root for the disaster variable. The PP-Fisher test results reject the unit root for all fiscal variables, while the IPS and the ADF-Fisher test results fail to reject the unit root forgovcon, govrev, govpay, and govdebt. 
Table 3B. Panel Unit Root Test Results: Developing Countries

Null Hypothesis: Unit Root

\begin{tabular}{lrrrrrr}
\hline \multirow{2}{*}{ Variable } & \multicolumn{2}{c}{ IPS } & \multicolumn{2}{c}{ ADF-Fisher } & \multicolumn{2}{c}{ PP-Fisher } \\
\cline { 2 - 7 } & W-stat & P-value & $\begin{array}{c}\text { Chi- } \\
\text { square }\end{array}$ & P-Value & $\begin{array}{r}\text { Chi- } \\
\text { square }\end{array}$ & P-value \\
\hline dam & -21.004 & 0.000 & 473.224 & 0.000 & 565.735 & 0.000 \\
govcon & -5.863 & 0.000 & 125.510 & 0.000 & 138.972 & 0.000 \\
govrev & -4.323 & 0.000 & 91.089 & 0.000 & 107.095 & 0.000 \\
govpay & -4.924 & 0.000 & 89.935 & 0.000 & 146.984 & 0.000 \\
govsurp & -9.566 & 0.000 & 177.025 & 0.000 & 282.540 & 0.000 \\
govdebt & -1.802 & 0.036 & 28.986 & 0.011 & 29.160 & 0.010 \\
\hline
\end{tabular}

Notes: (1) Variables shown are transformed variables using time-demeaned and Helmert fixed-effects transformation methods. (2) Lag length selection is based on AIC criteria. (3) IPS test is the test proposed by Im, Pesaran, and Shin (2003), (4) ADF-Fisher, and PP-Fisher tests are Fisher-type tests using ADF and PP proposed by Maddala and Wu (1999). (5) The test results for time-demeaned variables (without Helmert) are not shown here. However, we find that the PP-Fisher test results reject the unit root for all variables, while the IPS and the ADFFisher test results fail to reject the unit root for govdebt.

\section{Results}

Figures $1 A$ and $1 B$ show impulse-response dynamic s of a disaster shock on the fiscal variables for developed and developing countries from the baseline model as specified in equation (1). We set the magnitude of the disaster shock to two standard deviations because we want to examine the impact of large scale disasters. We summanize the cumulative fiscal impact of a large (2 STD) natural disa ster over the first six quarters in Table 4A and 4B.

For developed countries, we find that the govemment consumption ratio rises on impact ( $0.04 \%$ of G DP) and gradua lly dec lines thereafter. The govemment revenue drops immediately (-1.27\% of G DP) with negative cumulative impact, despite some improvements overtime. The govemment payment, on the other hand, inc reases on impact ( $0.46 \%$ of GDP) reaching its peak in the third quarter. The govemment cash surplus is negative on impact which is equivalent to being a net borrower (- $-2.28 \%$ of GDP) and continually getting worse. Finally, the govemment outstanding debt increases following the 
shock ( $1.07 \%$ of GDP), accumulating more than $8 \%$ of GDP over a year and a half. 
Table 4A. Cumulative Impact Developed Countries

\begin{tabular}{lr}
\hline Variable & dam \\
\hline govcon & -0.112 \\
govrev & -2.897 \\
govpay & 2.378 \\
govsump & -2.078 \\
govdebt & 8.093 \\
\hline \multicolumn{2}{l}{ From the baseline model with 4 lags. }
\end{tabular}

The dynamic responses of developing countries a re quite different from those of developed countries. Developing countries pursue a la rgely procyc lical fiscal policy following a large natural disaster shock. On impact, govemment consumption, govemment revenue, govemment payment, and outstanding debt response negatively, whereas the govemment cash surplus increases. The cumulative impact shown in Table $4 \mathrm{~B}$ below emphasizes this surprising pro-cyclic al behavior even more. The cumulative govemment consumption expenditure and govemment payment dec line $(-0.68 \%$ and $-0.33 \%$ of GDP), govemment revenue and cash surplus rise ( $4.23 \%$ and $2.79 \%$ of GDP), and outstanding debt decreases (- $-0.72 \%$ of GDP). ${ }^{9}$

Table 4B. Cumulative Impact Developing Countries

\begin{tabular}{lr}
\hline Variable & dam \\
\hline govcon & -0.679 \\
govrev & 4.226 \\
govpay & -0.330 \\
govsurp & 2.792 \\
govdebt & -0.724 \\
\hline From the baseline model with 4 lags.
\end{tabular}

\section{Robustness}

\footnotetext{
9 This finding of pro-cyc lic al fiscal policy in developing countries is corroborated by llzetzki and Végh (2008). They do not examine natural disasters, but demonstrate that unlike developed countries, developing countries follow a pro-cyclical fiscal policy in their reaction to business cycle changes.
} 
In the baseline model, we estimate the PVAR model using four lags based on the AIC (with quarterly data). In this section, we expand the lag length to six and eight lags, to generate the corresponding impulse-response function and cumula tive impact. For both sub-samples, results are to a large extent robust and similar to the four lags estimations. However, for the developed countries sample, estimates of the cumula tive impact on revenues appears to be sensitive to the number of lags used, while for the developing countries sample, results for payments a re apparently not robust. The impulse-response graphs from a model with eight lags are shown in Figure $2 \mathrm{~A}$ and $2 \mathrm{~B}$, and their cumula tive impacts are reported in Table 5A and 5B. ${ }^{10}$

Table 5A. Cumulative Impact Developed Countries

\begin{tabular}{lrr}
\hline Variable & 6 -lag & 8 -lag \\
\hline govcon & -0.114 & -0.081 \\
govrev & -4.367 & 1.682 \\
govpay & 1.588 & 1.780 \\
govsurp & -1.551 & -1.570 \\
govdebt & 5.077 & 5.606 \\
\hline
\end{tabular}

From the model with 6 or 8 lags.

Table 5B. Cumulative Impact Developing Countries

\begin{tabular}{lrr}
\hline Variable & $6-$ lag & 8 -lag \\
\hline govcon & -0.978 & -0.535 \\
govrev & 4.508 & 3.669 \\
govpay & 1.857 & -3.250 \\
govsurp & 2.039 & 2.070 \\
govdebt & -3.219 & -2.777 \\
\hline
\end{tabular}

From the model with 6 or 8 lags.

In addition, we split the developing countries subsa mple into uppermiddle income and lower-middle income countries. Figure $3 \mathrm{~A}$ and $3 \mathrm{~B}$ show their impulse-response graphs and Table 6A and 6B report their cumulative impacts.

\footnotetext{
10 To save space, we do not show the impulse-response graphsfrom the model with 6 lags; though they are very similar. Results a re available from the a uthors upon request.
} 
We find that in the cumulative impact, pro-cyclical fiscal policy is to large extent stronger in the lower-income developing countries, suggesting a decreasing ability to use fiscal policy to withstand extemal negative shocks that is associated with lower income. 
Table 6A. Cumulative Impact Upper-Middle Income Countries

\begin{tabular}{lr}
\hline Vaniable & dam \\
\hline govcon & 0.128 \\
govrev & 3.940 \\
govpay & -4.169 \\
govsurp & 2.906 \\
govdebt & -2.398 \\
\hline From the baseline model with 4 lags.
\end{tabular}

Table 6B. Cumulative Impact Lower-Middle Income Countries

\begin{tabular}{lr}
\hline Variable & dam \\
\hline govcon & -0.938 \\
govrev & -2.336 \\
govpay & -6.614 \\
govsum & 1.918 \\
govdebt & N/A \\
\hline From the baseline model with 4 lags.
\end{tabular}

\section{Fiscal projections for 2 prototypical cases}

One of the purposes for this work is to equip polic y makers with an estimate of the likely impact of a large natural disaster on their govemment accounts. Since different countries have different vulnerabilities to disasters - both in terms of occurrence probabilities, and the different disaster scales, we calculate for several countries the average magnitude of a 2-standard-deviations disa ster and from that calculate the disa ster's likely fiscal impact. The disaster data for specific countries are presented in table 7 while the cumulative fiscal impacts are presented in table 8.

Table 7. Summary Statistics of Disaster Variable for Selected Countries

\begin{tabular}{lrrrrr}
\hline \multicolumn{1}{c}{ Country } & $\begin{array}{c}\text { Disaster } \\
\text { Quarter }\end{array}$ & Mean & $\begin{array}{c}\text { Strd. } \\
\text { Dev. }\end{array}$ & Min & Max \\
\hline Developed countries: & 59 & 0.059 & 0.173 & 0.000 & 1.197 \\
USA & 19 & 0.289 & 0.632 & 0.002 & 2.483 \\
Germany & & & & & \\
\hline Upper-middle income & & & & & \\
countries: & 19 & 0.093 & 0.136 & 0.001 & 0.496 \\
Mexic o & 8 & 0.076 & 0.140 & 0.000 & 0.411 \\
South Africa & & & & & \\
\hline $\begin{array}{l}\text { Lower-middle income } \\
\text { countries: }\end{array}$ & & & & &
\end{tabular}


\begin{tabular}{lllllr} 
Indonesia & 24 & 1.701 & 6.042 & 0.004 & 29.179 \\
Philippines & 41 & 0.904 & 2.009 & 0.001 & 8.371 \\
\hline
\end{tabular} Notes: All sta tistic s a re calc ulated from disa ster episodes.

Table 8 provides us with the magnitude of the estimated fiscal effects for several countries. These estimates a re based on the regression results presented in tables 4A, 6A and 6B. The table clearly demonstrates that while our empincal exerc ise was aimed at estimating the a verage effect of a disaster on fiscal variables, the actual magnitude of the estimated effects a re different across different countries as these countries face different disaster probabilities and different distributions of the disaster magnitude.

Table 8. Cumulative Impacts - Selected Countries

\begin{tabular}{lrrrrrr}
\hline Variable & USA & Germany & Mexic o & S. Africa & Indonesia & Philippines \\
\hline govcon & -0.027 & -0.096 & 0.008 & 0.009 & -1.660 & -0.553 \\
govrev & -0.695 & -2.491 & 0.236 & 0.276 & -4.135 & -1.378 \\
govpay & 0.571 & 2.045 & -0.250 & -0.292 & -11.707 & -3.902 \\
govsurp & -0.499 & -1.787 & 0.174 & 0.203 & 3.395 & 1.132 \\
govdebt & 1.942 & 6.960 & -0.144 & -0.168 & N/A & N/A \\
\hline
\end{tabular}

From the baseline model with 4 lags.

\section{Policy conclusions}

We estimated the fiscal consequences of natural disa sters using quarterly fiscal data for a panel of 22 developed and 20 developing countries for 1990 2005 using VARs, as in Bumside et al. (2004). In our estimations, we employ a panel VAR fra mework that a lso controls for the business cycle and was developed by Love and Zcchino (2006). We find fiscal behavior in the aftemath of disasters to be different between developed and developing countries. In developed countries, govemments seem to be 'leaning aga inst the wind' and increasing spending and cutting taxes following a large disaster event. On the other hand, fiscal policy in developing countries can best be described as procyclical; with govemments largely decreasing spending and increasing revenues in the aftermath of large natural disaster events. 
While we cannot conclude anything about the reasons behind this differentiated behavior, we observe that this counter-intuitive pro-cyclical fiscal policy in developing countries is well documented in other contexts, most recently by llzetzki and Végh (2008). These findings suggest an extra urgency to develop insurance mechanisms that will enable govemments to insure a gainst these adverse fiscal consequences. This need is especially acute in developing countries, since the pro-cyclical policy adopted in the aftemath of the disaster leads to furtherand deeperadverse macro-economic outcomesas a result of these events.

Our qua ntitative results suggest the exact a mount of coverage that govemments need to accumula te to insure aga inst these adverse outcomes. For example, given the results we present in table 8 , we suggest that given past experiences, the Indonesian govemment should insure itself, perhaps through the issuance of CATbonds, to a larger extent than the Philippine govemment. These a re preliminary results, and while suggestive, a mechanism to measure more precisely the amount of insurance needed to account for both the occasional large scale disaster together with frequent smaller disasters needs to be developed.

Once we obtain a benchmark for the likely fiscal dyna mics after a disaster event, we can also start to examine the deteminants of these effects. For example, different public response to disaster damage may depend on the govemment accountability to the electorate; i.e., more democratic and competitive regimes with freer speech/press and more transpa rent institutions a re likely to respond more a ggressively to disasters tha n countries whose govemments are not responsive or accountable to the population. Besley and Burgess (2002) and before them Sen (1980) suggest several hypotheses that can potentially be examined with more detailed fiscal and disaster data, or data at the sub-national level. 
Figure 1A. Selected Impulse-Response Graphs from the Baseline Model for Developed Countries (Two-Standard-Deviation Disaster Shock)
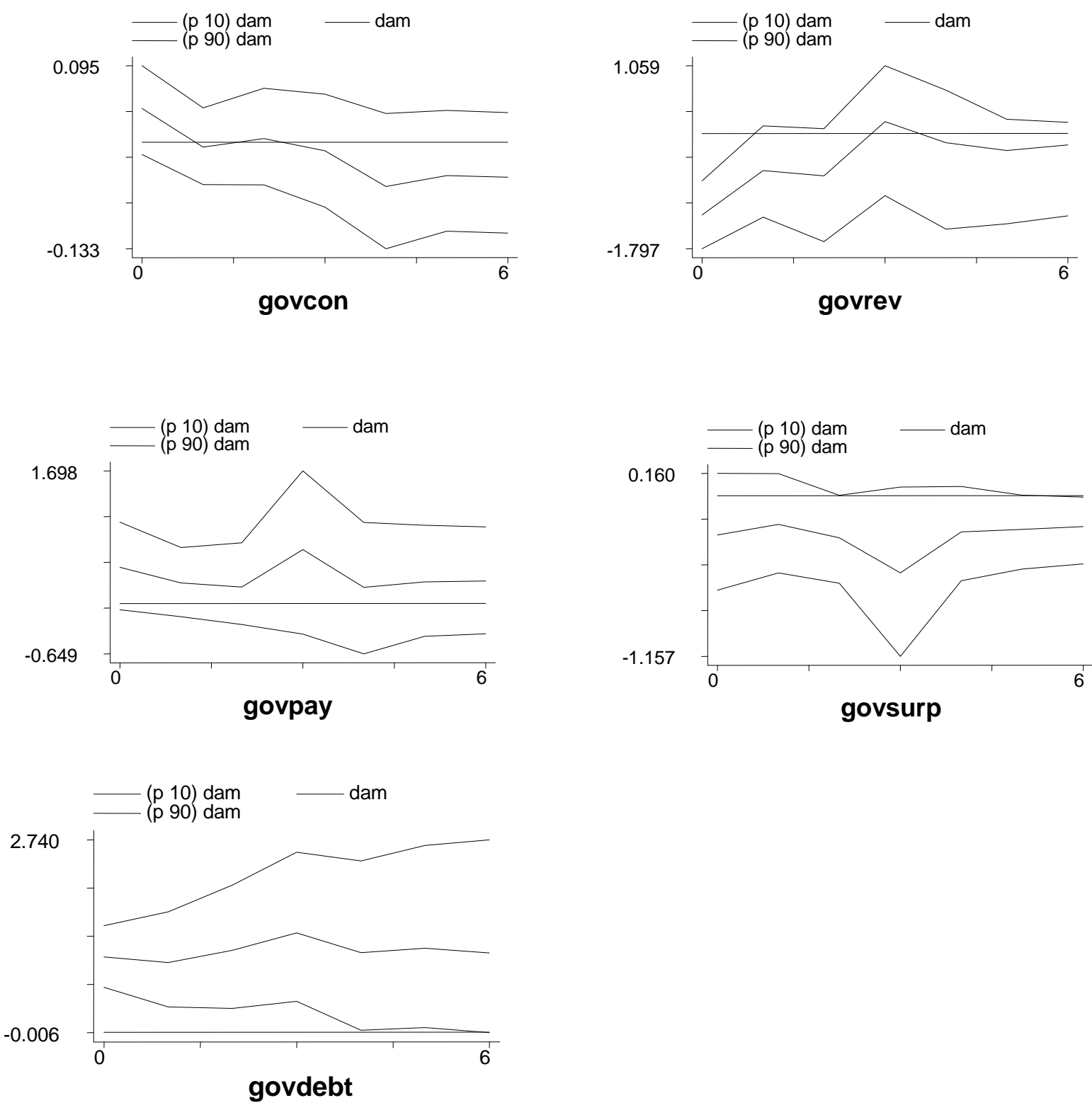
Figure 1B. Selected Impulse-Response Graphs from the Baseline Model for Developing Countries (Two-Standard-Deviation Disaster Shock)
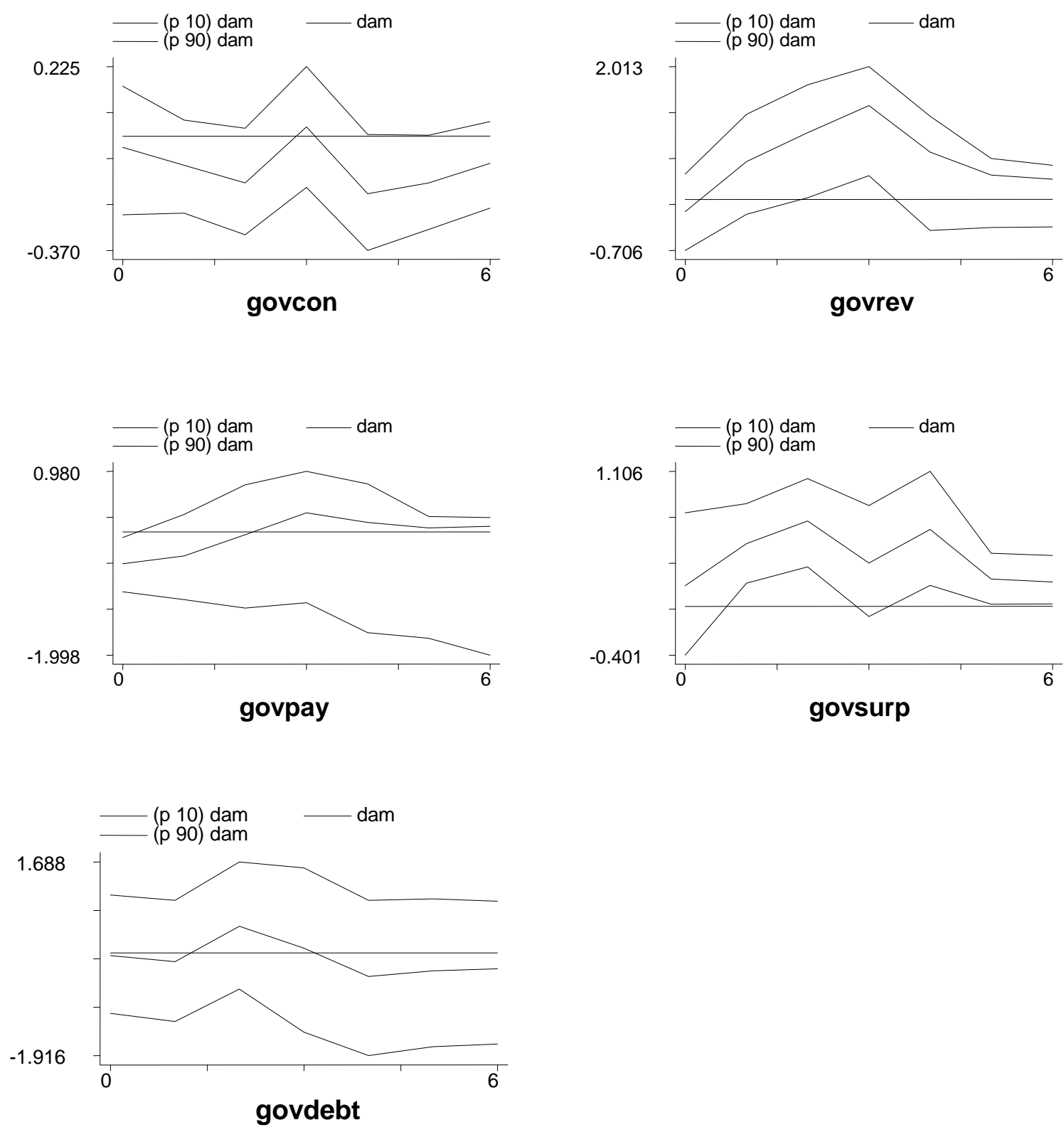
Figure 2A. Selected Impulse-Response Graphs from the Model with 8 Lags for Developed Countries (Two-Standard-Deviation Disaster Shock)
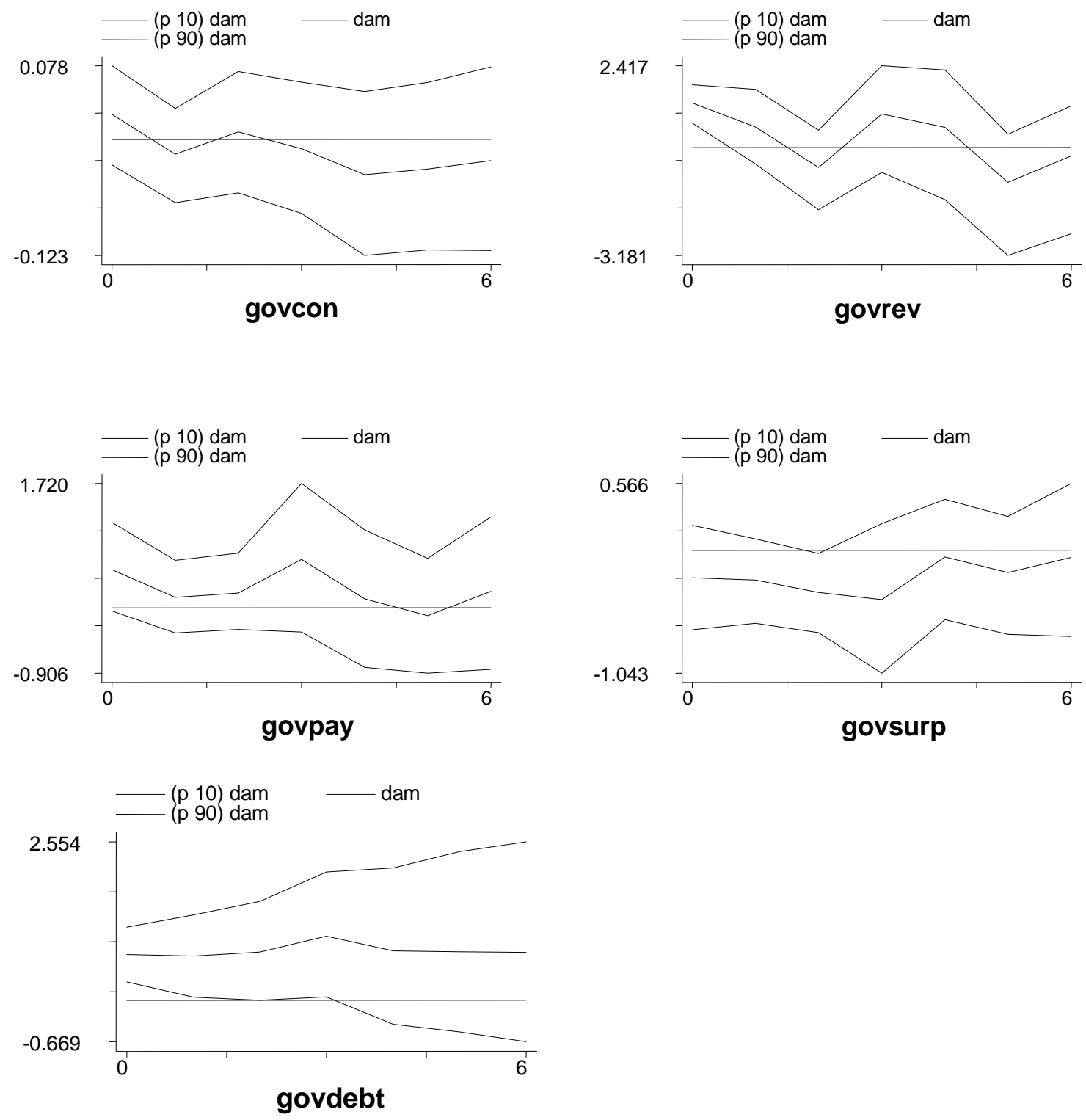
Figure 2B. Selected Impulse-Response Graphs from the Model with 8 Lags for Developing Countries (Two-Standard-Deviation Disaster Shock)
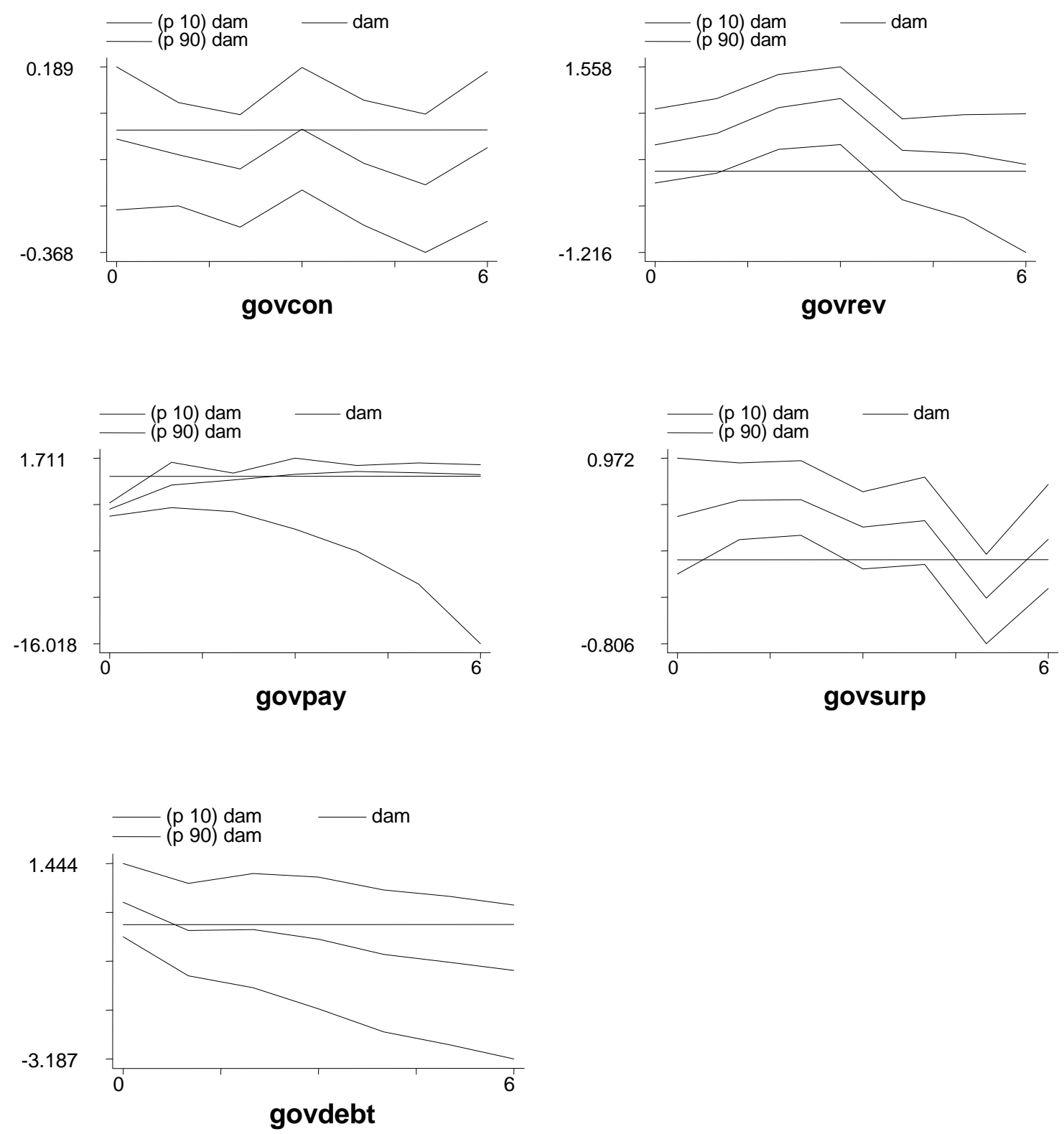
Figure 3A. Selected Impulse-Response Graphs from the Baseline Model for Upper-Middle Income Countries (Two-Standard-Deviation Disaster Shock)
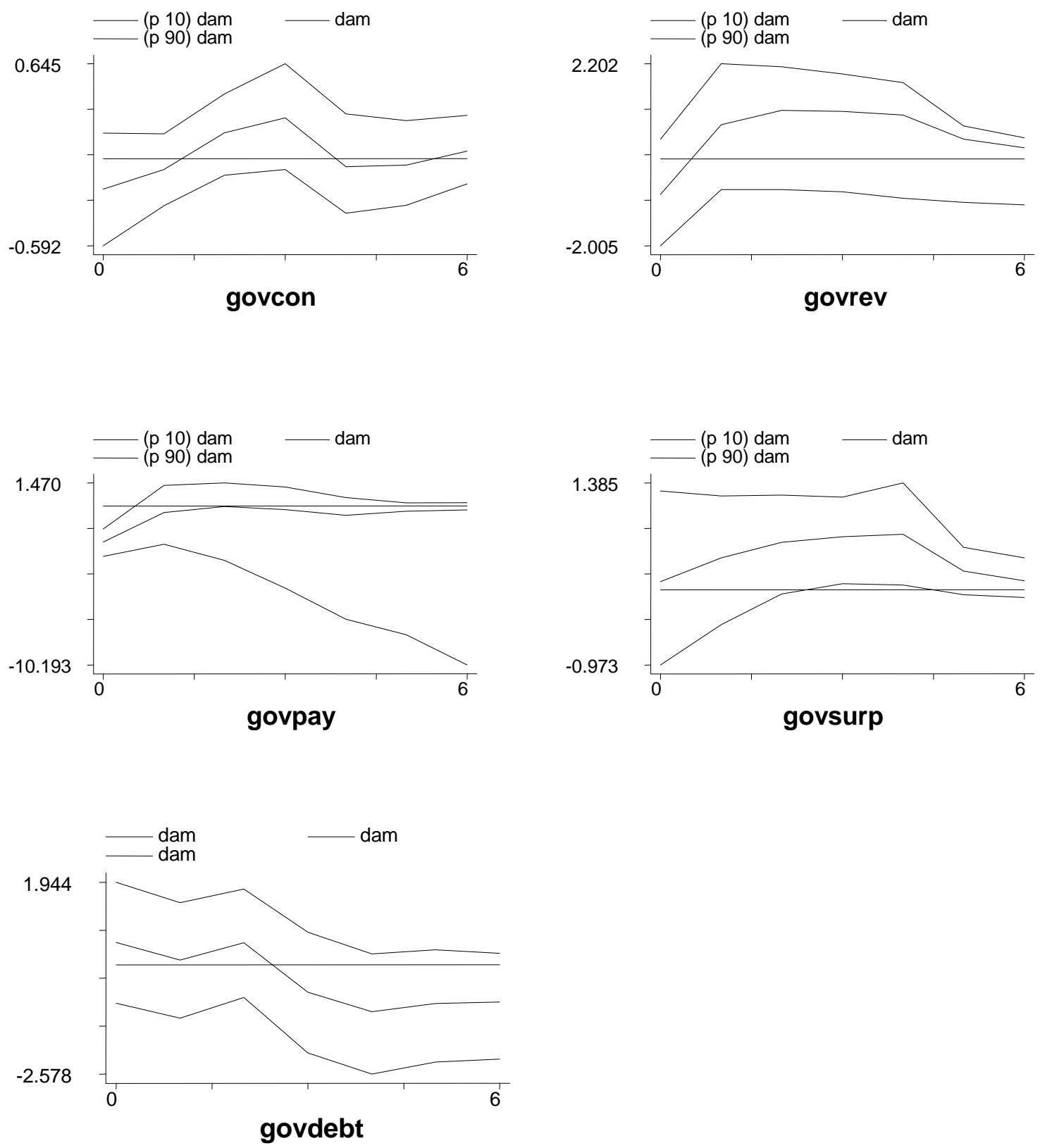
Figure 3B. Impulse-Response Graphs from the Baseline Model for LowerMiddle Income Countries (Two-Standard-Deviation Disaster Shock)
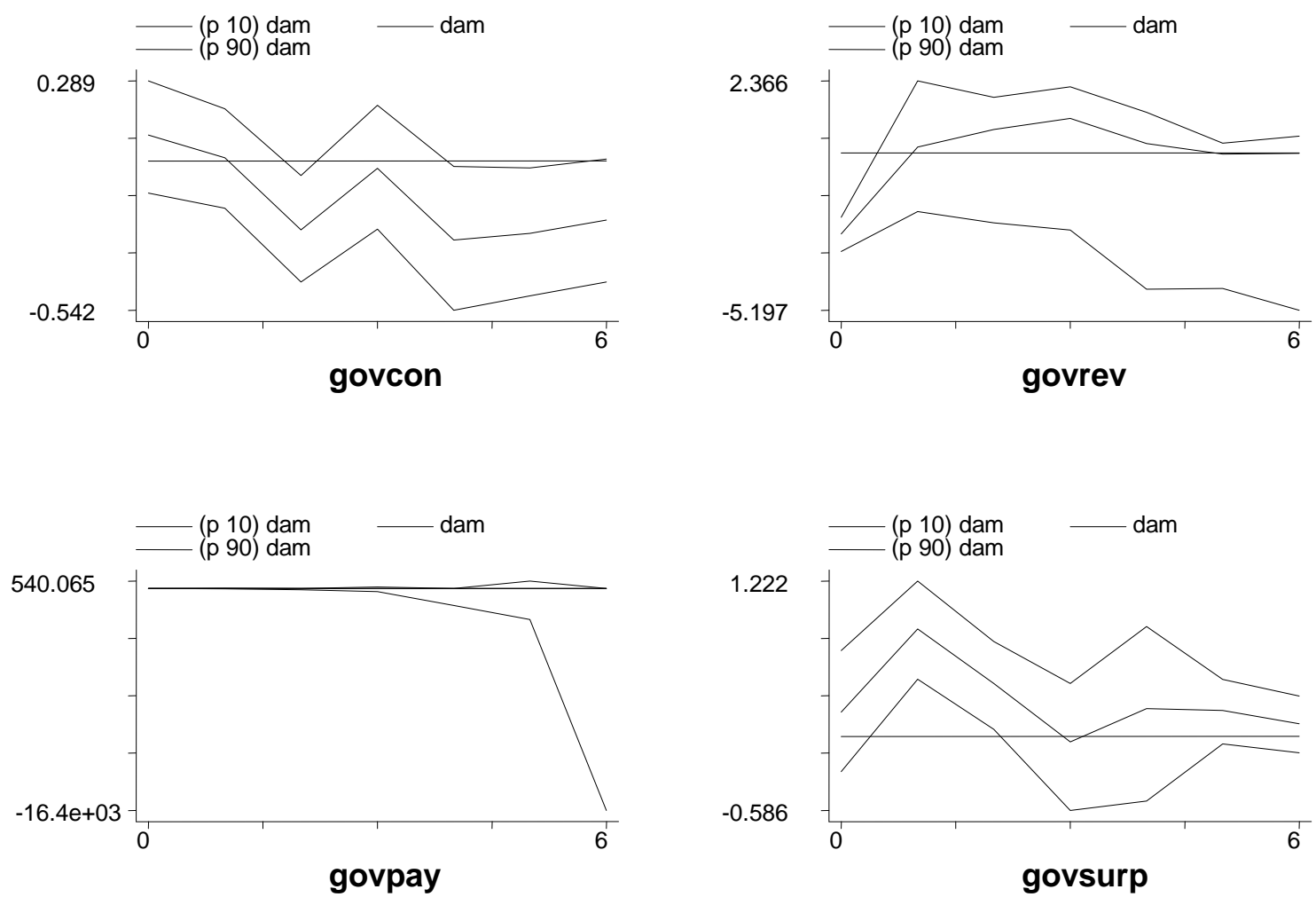
Appendix: List of Countries

\begin{tabular}{|c|c|c|}
\hline Developed & $\begin{array}{l}\text { Developing: } \\
\text { Upper-Middle } \\
\text { Income }\end{array}$ & $\begin{array}{l}\text { Developing: } \\
\text { Lower-Middle Inc ome }\end{array}$ \\
\hline $\begin{array}{l}\text { Australia } \\
\text { Austria } \\
\text { Belgium } \\
\text { Canada } \\
\text { Denmark } \\
\text { Finland } \\
\text { France } \\
\text { Germany } \\
\text { Iceland } \\
\text { Ireland } \\
\text { Italy } \\
\text { Japan } \\
\text { Korea } \\
\text { Netherlands } \\
\text { New Zealand } \\
\text { Norway } \\
\text { Portugal } \\
\text { Spain } \\
\text { Sweden } \\
\text { Switzerland } \\
\text { United Kingdom } \\
\text { United States }\end{array}$ & $\begin{array}{l}\text { Argentina } \\
\text { Botswana } \\
\text { Brazil } \\
\text { Chile } \\
\text { Cyprus } \\
\text { Israel } \\
\text { Malaysia } \\
\text { Mexico } \\
\text { Poland } \\
\text { South Africa } \\
\text { Turkey }\end{array}$ & $\begin{array}{l}\text { Bolivia } \\
\text { Colombia } \\
\text { Ecuador } \\
\text { Guatema la } \\
\text { Indonesia } \\
\text { Iran } \\
\text { Peru } \\
\text { Philippines } \\
\text { Thailand }\end{array}$ \\
\hline
\end{tabular}




\section{References:}

Anbarci, N., Escaleras, M., and Register, C. A, 2005. Earthquake Fatalities: The Interaction of Nature and Politic al Economy. J oumal of Public Ec onomics, 89, 1907-1933.

Ba michon, Régis, 2008. Intema tional Reserves and Self-Insura nce aga inst Extemal Shocks. IMF Working Paper 08/149.

Besley, Timothy And Robin Burgess, 2002. The politic al economy of govemment Responsiveness: Theory and Evidence from India. Quarterly J oumal of Ec onomics, November, 1415-1451.

Blanchard, Olivier and Roberto Perotti, 2002. An empiric al characterization of the dynamic effects of changes in govemment spending and taxes on output. Quarterly J oumal of Economic s November, 1329-1368.

Bo rensztein, Eduardo, Eduardo Cavallo, and Patric io Valenzuela, 2008. Debt Susta ina bility under Catastrophic Risk: The Case for Govemment Budget Insurance. IMF Working Paper WP/08/44.

Bumside, Craig, Martin Eic henbaum, and J onas D.M. Fisher, 2004. Fiscal shocks and their consequences. J oumal of Ec onomic Theory 115, 89-117.

Cuaresma, J.C., Hlouskova, J ., and M.O bersteiner, 2008. Na tural disa sters as creative destruction? Evidence from developing countries. Economic Inquiry 46(2); 214-226.

Eichenbaum, Martin and J onas D.M. Fisher, 2005. Fiscal Policy in the Aftermath of 9/11. J oumal of Money, Credit, and Banking 37(1), 1-22.

Fengler, Wolfgang, Ahya Ihsan and Kai Ka iser, 2008. Managing Post-Disaster Reconstruction Finance: Intemational Experience in Public Financial Management. World Bank Policy Research Working Paper 4475.

Ilzetzki, Ethan and Carlos A. Végh, 2008. Procyclical Fiscal Policy in Developing Countries: Truth or Fic tion? NBER Working Paper No. 14191.

Im, K., M.H., Pesaran, and Y. Shin, 2003. Testing for Unit Roots in Heterogenous Panels. J oumal of Ec ono metric s 115, 53-74.

Kahn M E. The death toll from natural disasters: The role of income, geography, and institutions. Review of Ec ono mic s and Sta tistic s 2004;87(2); 271-284. 
Love, Inessa and Lea Zcchino, 2006. Financial development and dynamic investment behavior. Evidence from panel VAR. Quarterly Review of Economics and Finance 46, 190-210.

Maddala, G. S., and S. Wu, 1999. A Compa rative Study of Unit Root Tests with Panel Data and New Simple Test. Oxford Bulletin of Ec onomic s and Statistics, 61, 631-652.

Noy, llan, 2009. The Macroeconomic Consequences of Disasters. J oumal of Development Economics, 88(2), 221-231.

Raschky, P. A., 2008. Institutions and the losses from natural disa sters. Natural Haza rds Earth Systems Sc ience 8, 627-634.

Skidmore M, Toya H., 2002. Do natural disasters promote long-run growth? Economic Inquiry 40(4); 664-687.

Skidmore $M$, Toya H., 2007. Economic development and the impacts of natural disasters. Ec onomic Letters 94; 20-25. 